\title{
Angiotensin-converting enzyme insertion/ deletion (I/D) gene polymorphism in Iraqi type 2 diabetic patients: association with the risk of cardiac autonomic neuropathy
}

\author{
Muhanad M. Dhumad ${ }^{1}$, Farqad B. Hamdan ${ }^{2^{*}}$ (D) and Qasim S. Al-Mayah ${ }^{3}$
}

\begin{abstract}
Background: Studies have shown a direct association between angiotensin-converting enzyme (ACE) and diabetic neuropathies. As such, ACE gene polymorphisms could be a risk factor for cardiac autonomic neuropathy (CAN) in patients with diabetes. The objective of our study was to investigate the association of the ACE I/D gene polymorphism with the development of CAN in Iraqi patients with type 2 diabetes mellitus (T2DM).

Results: This is a cross-sectional study that included 142 patients with T2DM comprising 62 males and 80 females, and 100 volunteers served as a healthy control group. Cardiac autonomic functions were tested using four standard Ewing's noninvasive tests. Blood samples were taken for genetic evaluation of an ACE gene I/D polymorphism. Analyzing ACE gene polymorphism revealed that the $D$ allele was far more frequent among patients with diabetes than healthy control subjects (76.07\% vs. 62.67\%). The frequency of I/I, I/D, and D/D genotypes in patients with diabetes was $8.55 \%, 30.77 \%$, and $60.68 \%$, respectively, compared with $18.67 \%, 37.33 \%$, and $44 \%$, respectively, in controls with a significant difference in mutant homozygous genotype. However, there were no significant differences in these genotypes between patients with and without CAN. Although patients with CAN showed a much higher frequency of $D$ allele than those without CAN, the difference did not reach significance $(p=0.054)$.

Conclusion: The DD genotype and D allele of the ACE I/D gene polymorphism can be a risk factor for T2DM, and the $\mathrm{D}$ allele of this polymorphism can even be associated with the development of CAN in these patients.
\end{abstract}

Keywords: DM, Cardiac autonomic neuropathy, ACE gene polymorphism

\section{Background}

Neurovascular complications affect more than $60 \%$ of patients with type 2 diabetes mellitus (T2DM), among which is cardiac autonomic neuropathy (CAN) [1]. According to the Subcommittee of the Toronto Consensus Board on Diabetic Neuropathy, CAN was defined as the impairment of cardiovascular autonomic control in patients with diabetes after the elimination of other causes [1].

\footnotetext{
* Correspondence: farqadbhamdan@colmed-alnahrain.edu.iq;

farqadbhamdan@yahoo.com

${ }^{2}$ Department of Physiology, College of Medicine, Al-Nahrain University, P.O.

Box 14222, Baghdad, Iraq

Full list of author information is available at the end of the article
}

Diabetic neuropathies, in general, have complex disease etiologies, the most important of which is chronic hyperglycemia, which may contribute to its pathogenesis by causing changes in gene expression, inflammation, and oxidative stress $[2,3]$.

Gene sequencing technologies have identified several genes such as TCF7L2, APOE, and ACE, which may influence the development of T2DM and CAN [4].

Angiotensin-converting-enzyme (ACE) is a zincdependent relatively nonspecific peptidase encoded by the $A C E$ gene. The ACE protein is capable of cleaving a wide range of substrates. By cutting angiotensin I at a specific location, the renin-angiotensin system (RAS) will 
convert angiotensin I into angiotensin II (Ang II) [5], which plays a role in the regulation of glucose and insulin levels. Hyperglycemia that induced by high Ang II levels has been considered as a risk for T2DM [6].

Furthermore, Ang II influences the autonomic nervous system by stimulating the sympathetic system and inhibit parasympathetic outflow. Alternatively, when Ang II is blocked, a reduction in sympathetic activity and an enhancement of parasympathetic activity are expected [7].

The ACE gene is located on chromosome $17 \mathrm{q} 23$ comprising $21 \mathrm{~kb}$ [8]. The insertion/deletion (I/D) polymorphism of $A C E$ is characterized by the presence (insertion) or absence (deletion) of a $287 \mathrm{bp}$ Alu repeat sequence in intron 16 producing three genotypes (II homozygote, ID heterozygote, and DD homozygote) [8]. It was reported that individuals with the DD genotype have higher tissue and plasma ACE concentrations than either ID of II genotypes [9].

Various reports have been published suggesting interethnic variations in the frequency of allelic forms of the $A C E$ genes $[10,11]$. Conflicting results have been reported regarding the association between the $A C E$ polymorphism and the development of CAN in patients with T2DM [12-14].

Although the association of $A C E$ gene I/D polymorphisms with diabetes has been extensively studied in different populations, there are no such studies among Iraqi population. We thereby aimed to investigate the distribution and association of $A C E$ gene I/D polymorphism in Iraqi diabetic patients with CAN.

\section{Methods}

A cross-sectional study was conducted from November 2018 to August 2019. One hundred forty-two patients with T2DM who were attending the diabetic clinic at Al-Imamain Al-Kadhumain Medical City/Baghdad/Iraq, comprising 62 males and 80 females with an age range from 41 to $68(53.35 \pm 7.83)$ years were enrolled in this study. The duration of their illness ranged from 1 to 15 (5.39 \pm 4.75$)$ years. Diagnosis of T2DM was based on symptoms of diabetes plus a random blood glucose concentration of $\geq 200 \mathrm{mg} / \mathrm{dL}$, fasting plasma glucose $\geq 126$ $\mathrm{mg} / \mathrm{dL}$, and 2-h plasma glucose $\geq 200 \mathrm{mg} / \mathrm{dL}$ during an oral glucose tolerance test.

Patients with uncontrolled hypertension, ischemic heart disease, valvular heart disease, arrhythmia, including atrial fibrillation heart failure, severe illness, such as malignancy and severe infection, liver cirrhosis, prostatic enlargement, gestational diabetes, severe hypoglycemia, alcoholism, and those on beta-blocker medication were excluded from the study.

Another 100 age- and sex-matched healthy subjects comprising 39 males and 61 females served as a control group. Their ages ranged from 35 to $65(51.73 \pm 8.81)$ years.

\section{Medical history and examination}

A detailed medical history and clinical examination were performed by a senior dialectologist including signs and symptoms of DM. Body weight, height, body mass index (BMI), and waist-hip ratio (WHR) were obtained. General urine examination, albuminuria, fasting plasma glucose, glycosylated hemoglobin (HbA1c), lipid profile, and renal function test (if available) were also performed.

\section{Cardiac autonomic functions}

Cardiac autonomic functions were tested using four standard Ewing's noninvasive tests [15].

1. Parasympathetic autonomic function tests for cardiovagal regulation which includes the following:

a) Heart rate (HR) response to deep breathing test

While the subjects were in the supine position with all electrocardiography (ECG) leads attached, they were asked to breathe normally for $2 \mathrm{~min}$, then asked to perform 6 maximum deep breaths in $1 \mathrm{~min}$. The expiration: inspiration (E:I) ratio was obtained using the following formula:

$\mathrm{E}: \mathrm{I}$ ratio $=$ mean value of the longest $\mathrm{R}-\mathrm{R}$ interval during the expiration/mean value of the shortest $R-R$ interval during inspiration.

b) Immediate heart rate (HR) response to standing: during ECG recording, the subject was asked to lie quietly for $3 \mathrm{~min}$, then asked to stand up and remain motionless (a point was marked on the electrocardiogram (ECG) paper to identify the point of standing). The 30:15 ratio was calculated by taking the ratio of the R-R interval at the 30th beat and 15 th beat after standing.

2. Sympathetic autonomic function tests for adrenergic vascular regulation which includes the following:

a) Blood pressure (BP) response to standing: the patients' BP was measured while they were lying down quietly and again when they stood up 1-2 min after standing. The postural fall after $2 \mathrm{~min}$ in $\mathrm{BP}$ was taken as the difference between BP (systolic and diastolic $\mathrm{BP}$ ) lying and the $\mathrm{BP}$ (systolic and diastolic BP) standing.

b) $\mathrm{BP}$ response to sustained handgrip test: the BP response to static exercise. The participants were asked to apply pressure on a handgrip for $1 \mathrm{~min}$ at 
$30 \%$ of maximal voluntary contraction, and simultaneously changes in BP were observed using a sphygmomanometer. The difference between the diastolic BP just before the release of contraction and before the handgrip began was taken as a measure of the response.

The patients were asked to fast for $12 \mathrm{~h}$ and to avoid taking antidepressants, neuroleptics, caffeine, nicotine, or antihistamines before the procedure. The tests were carried out between 07:00 and 09:00 AM in a quiet environment with steady temperature levels between 22 and $24^{\circ} \mathrm{C}$ [16].

Variation in HR during deep breathing (E:I ratio) were considered normal if its value was $\geq 1.21$ and abnormal if it was $\leq 1.10$; the value of the immediate HR response to standing was considered normal when it was $\geq 1.04$ and abnormal if it was $\leq 1.00$; the value of BP response to standing was considered normal when it was $\leq 10$ and abnormal when it was $\geq 30$, and the value of $\mathrm{BP}$ response to sustained handgrip was considered normal when it was $\geq 16$ and abnormal when it was $\leq 10$ [17].

\section{Genetic study}

Peripheral blood samples $(2 \mathrm{~mL})$ were taken from 117 patients with diabetes (62 without CAN and 55 with CAN) and 75 healthy control subjects, in labeled ethylenediamine-tetraacetic acid (EDTA) tubes for genetic evaluation of $A C E$ gene I/D polymorphism.

\section{Gene amplification and genotyping}

Deoxyribonucleic acid was extracted from blood samples using a ready kit $\left(\mathrm{gSYNC}{ }^{\mathrm{TM}}\right.$ DNA Mini Kit Whole Blood Protocol/Geneaid/Korea) according to the manufacturer's instructions. The extracted DNA from blood samples was used in a polymerase chain reaction (PCR) for amplification of the $A C E$ gene fragment corresponding to the $\mathrm{I} / \mathrm{D}$ polymorphism identification.

A pair of primers specific for this single-nucleotide polymorphism (SNP) (forward, 5 ' -CTG GAG ACC ACT CCC ATC CTT TCT-3' and reverse, 5'-GAT GTG GCC ATC ACA TTC GTC AGA-3) was used. The PCR was conducted on a Hybaid/England thermocycler in a total volume of $50 \mu \mathrm{L}$ containing $0.4 \mu \mathrm{mol}$ forward primer, $0.4 \mu \mathrm{mol}$ reverse primer, DNA template $(2 \mathrm{ng}), 4$ mmol-1 $\mathrm{MgCl} 2$, Taq DNA polymerase $(0.05 \mu \mathrm{L})$, and dNTPs (dATP, dCTP, dGTP, and dTTP, $0.4 \mathrm{mmol}$ each) (Bioneer/Korea). The volume was adjusted to 50 by deionized water. Cycling parameters were as follows: an initial denaturation for $4 \mathrm{~min}$ at $95^{\circ} \mathrm{C}$ followed by $45 \mathrm{cy}$ cles of denaturation at $94{ }^{\circ} \mathrm{C}$, annealing at $61^{\circ} \mathrm{C}$ for $35 \mathrm{~s}$, and elongation at $72{ }^{\circ} \mathrm{C}$, for $45 \mathrm{~s}$. The final elongation was at $72{ }^{\circ} \mathrm{C}$ for $7 \mathrm{~min}$. The expected fragment length was $490 \mathrm{bp}$ for I allele and $190 \mathrm{bp}$ for the D allele. To verify the results, $10 \%$ of $\mathrm{PCR}$ products were sent to Macrogen, Korea for direct sequencing.

\section{Statistical analysis}

Continuous variables were analyzed using the independent $t$ test or with analysis of variance (ANOVA) and are expressed as mean standard deviation (SD), and dichotomous variables were analyzed using the chi-square test and are expressed as numbers and frequency. The risk association between the genotype and DM or CAN was estimated through the calculation of adjusted odds ratio (OR) and 95\% confidence intervals (CI) using multivariate logistic regression.

For this analysis, subjects who were homogenous for the wild type allele (allele I) were considered as reference, polymorphisms as dependent variables, and other risk factors (including age, sex, BMI, WHR, and smoking status) as co-variables in the model. Chi-square was used to test the deviation of genotypes from the HardyWeinberg equilibrium (HWE). A $p$ value $<0.05$ was considered statistically significant.

\section{Results}

\section{Characteristics of the studied population}

No significant difference was demonstrated between the patients with diabetes and the control group concerning age, weight, height, BMI, WHR, and current smoking (Table 1).

The cardiovascular autonomic tests for both studied groups are presented in Table 2. A significant difference between patients with DM and controls was demonstrated considering the HR response to deep breathing (E:I ratio), HR response to standing (30:15 ratio), orthostatic hypotension, and response to sustained handgrip $(p<0.001)$.

Table 1 Baseline characteristics of the study population

\begin{tabular}{llll}
\hline Variable & Diabetic mellitus $n=142$ & Controls $n=100$ & $p$ value \\
\hline $\begin{array}{l}\text { Age (years) } \\
\text { Sex }\end{array}$ & $53.35 \pm 7.83$ & $51.73 \pm 8.81$ & $0.109 \dagger$ \\
$\quad$ & & \\
Male & $62(43.66 \%)$ & $39(39 \%)$ & $0.469 \neq$ \\
$\quad$ Female & $80(56.34 \%)$ & $61(61 \%)$ & \\
Weight $(\mathrm{kg})$ & $84.16 \pm 10.64$ & $82.85 \pm 10.28$ & $0.061 \dagger$ \\
Height $(\mathrm{cm})$ & $170.6 \pm 12.85$ & $167.94 \pm 14.09$ & $0.116 \dagger$ \\
BMl (kg/m²) & $29.68 \pm 3.78$ & $29.16 \pm 4.6$ & $0.334 \dagger$ \\
Waist/hip ratio & $0.92 \pm 0.074$ & $0.93 \pm 0.128$ & $0.093 \dagger$ \\
Current smoking & $34(23.94 \%)$ & & \\
Yes & $108(76.06 \%)$ & $18(18 \%)$ & $0.268 \neq$ \\
No & $82(82 \%)$ & \\
\hline
\end{tabular}

CAN cardiac autonomic neuropathy, BMI body mass index, $\dagger t$ test, ₹ chi-square 
Table 2 Cardiovascular autonomic tests of the study population

\begin{tabular}{|c|c|c|c|c|}
\hline Test & & $\mathrm{DM} n=142$ & $\begin{array}{l}\text { Controls } \\
n=100\end{array}$ & $p$ value \\
\hline \multirow{2}{*}{$\begin{array}{l}\text { HR response } \\
\text { (E:I ratio) }\end{array}$} & Abnormal & 71 (50\%) & $4(4 \%)$ & \multirow[t]{2}{*}{$<0.001 \neq$} \\
\hline & Normal & 71 (50\%) & 96 (96\%) & \\
\hline \multirow{2}{*}{$\begin{array}{l}\text { HR response } \\
\text { (30:15 ratio) }\end{array}$} & Abnormal & $60(42.25 \%)$ & $1(1 \%)$ & \multirow[t]{2}{*}{$<0.001 \neq$} \\
\hline & Normal & $82(55.75 \%)$ & 99 (99\%) & \\
\hline \multirow{2}{*}{$\begin{array}{l}\text { BP response to } \\
\text { standing }\end{array}$} & Abnormal & $35(24.65 \%)$ & $0(0 \%)$ & \multirow[t]{2}{*}{$<0.001 \neq$} \\
\hline & Normal & 107 (75.35\%) & 100 (100\%) & \\
\hline \multirow{2}{*}{$\begin{array}{l}\mathrm{BP} \text { response to } \\
\text { sustained handgrip }\end{array}$} & Abnormal & $21(14.79 \%)$ & $0(0 \%)$ & \multirow[t]{2}{*}{$<0.001 \neq$} \\
\hline & Normal & 121 (85.21\%) & 100 (100\%) & \\
\hline
\end{tabular}

$D M$ diabetes mellitus, $\mathrm{HR}$ heart rate, $E: I$ expiration:inspiration, $B P$ blood pressure, $\neq$ chi-square

\section{Association of the ACE I/D gene polymorphism with the development of CAN}

PCR products were subjected to gel electrophoresis, from which three genotypes appeared: II, ID, and DD (Fig. 1). Furthermore, 10\% of the PCR product underwent direct sequencing to verify the result of gel electrophoresis. There was complete agreement between the two methods.

The frequency of the different genotypes of this polymorphism in patients with diabetes and control subjects was in a good agreement with the HWE. The frequency of II, ID, and DD genotypes in patients with diabetes was $8.55 \%, 30.77 \%$, and $60.68 \%$, compared with $18.67 \%$, $37.33 \%$, and $44 \%$, respectively, in the controls (Table 3 ) with a significant difference for the DD genotype (OR = 3.0, 95\% CI: [1.2-7.45], $p=0.018)$. At the allelic level, allele D was far more frequent among the patients with diabetes than in the controls $(76.07 \%$ vs. $62.67 \%)$ with a highly significant difference $(\mathrm{OR}=1.89,95 \% \mathrm{CI}$ : [1.212.96], $p=0.005$ ).

Table 4 illustrates the frequency of different genotypes and alleles of ACE I/D polymorphism in patients with and without CAN. There was a non-significant higher frequency of DD genotype in patients with CAN (69.1\%) in comparison with $53.23 \%$ in those without CAN (OR = 2.7, 95\% CI: [0.64-11.24], $p=0.176)$. At the allelic level, the frequency of $\mathrm{D}$ allele was higher in the diabetics with CAN than those without CAN (81.82\% vs. $70.97 \%)$; however, this difference did not reach the level of significance $(\mathrm{OR}=1.84,95 \% \mathrm{CI}$ : [0.99-3.42], $p=0.054)$.

\section{Discussion}

The focus has been placed on the early identification of intervention with patients genetically susceptible to diabetes because DM is a disease with serious chronic complications. The $A C E$ gene polymorphism was investigated in Iraqi patients with T2DM in the present study.

A strong link between the DD homozygous genotype and the $\mathrm{D}$ allele of the $A C E \mathrm{I} / \mathrm{D}$ gene polymorphism with T2DM was identified. The logistic regression analysis showed that the DD genotype was associated with a threefold increase in the risk of developing DM compared with healthy controls. Moreover, the D allele was far more frequent among patients than in controls. This denotes that the DD genotype and the D allele of the $A C E$ gene I/D polymorphism may contribute to the relatively high prevalence of DM in the Iraqi population [18]. It was well documented that individuals' homozygous for the D allele have plasma ACE levels about twice as high as those homozygous for I allele [19]. Within the RAS, ACE will convert Ang I to Ang II. Clinical studies have demonstrated that the relatively high Ang II may contribute to impaired insulin secretion and insulin resistance, thereby increasing the risk for T2DM. The detrimental effects of Ang II on insulin secretion seem to be mediated by a reduction in pancreatic blood flow and induction of islet fibrosis, oxidative stress, and inflammation, whereas both impaired skeletal muscle function (disturbances in skeletal muscle blood flow, insulin signaling, and mitochondrial function) and adipocyte dysfunction (adipocyte hypertrophy, inflammation, and impairments in lipid metabolism) may underlie Ang IIinduced insulin resistance [20].

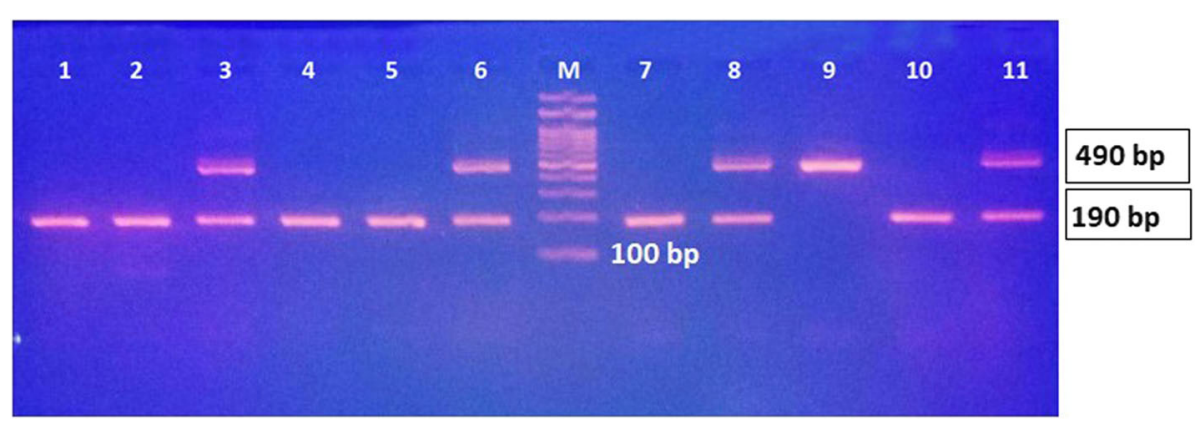

Fig. 1 Gel electrophoresis of ACE ID gene polymorphism amplified with a specific pair of primers using conventional PCR. The PCR products were stained with ethidium bromide. Lanes 1, 2, 4, 5, 7, and 10: homozygous DD genotypes; lanes 3, 6, 8, and 11: heterozygous ID genotypes; lane 9: homozygous II genotypes 
Table 3 Frequency of different genotypes and alleles of the ACE ID polymorphism in patients with diabetes and controls

\begin{tabular}{lllll}
\hline $\begin{array}{l}\text { ACE ID } \\
\text { polymorphism }\end{array}$ & DM $n=117$ & $\begin{array}{l}\text { Controls } \\
n=75\end{array}$ & $p$ value & OR $(95 \% \mathrm{Cl})$ \\
\hline $\begin{array}{lllll}\text { Genotypes } \\
\text { II }\end{array}$ & $10(8.55 \%)$ & $14(18.67 \%)$ & 0.039 & 1.0 ref. \\
ID & $36(30.77 \%)$ & $28(37.33 \%)$ & 0.225 & $1.8(0.7-4.65)$ \\
DD & $71(60.68 \%)$ & $33(44 \%)$ & $0.018^{*}$ & $3.0(1.2-7.45)$ \\
HWE & 0.094 & 0.08 & & \\
Alleles & & & & \\
I & $56(23.93 \%)$ & $56(37.33 \%)$ & $0.005^{* *}$ & 1.0 ref. \\
D & $178(76.07 \%)$ & $94(62.67 \%)$ & & $1.89(1.21-2.96)$ \\
\hline
\end{tabular}

DM diabetes mellitus, HWE Hardy-Weinberg equilibrium (using logistic regression), *significant at 0.05 , **significant at 0.001

In agreement with the present study, many reports worldwide disclosed this link between ACE I/D polymorphism and T2DM, i.e., in Turkish hypertensive diabetics [21], Taiwanese [22], Iranians [23], Malaysians [24], Egyptians [25], Chinese [26], and Saudi populations [27]. By contrast, many studies failed to show this association [28, 29], some studies even showed an inverse association [30]. Similarly, the ACE I allele was found to be associated with T2DM in Japanese [31] and the $\mathrm{Ku}$ waiti populations [32].

The contradictory results regarding the involvement of the ACE I/D polymorphism in T2DM are likely to be due to variance in ethnicity, heterogeneity of populations, sampling bias, and potentially other ecologic factors [33, 34]. Furthermore, some environmental factors such as nutrition and physical activity have been associated with modification in epigenetic status [35, 36]. Therefore, such interaction between epigenetic modifications and polymorphisms describes the complexity of the genetic architecture that can underlie the inconsistency in association studies observed with the $A C E \mathrm{I} / \mathrm{D}$ polymorphism in different populations.
In the current study, there was a remarkable nonsignificant increment in the D allele frequency among diabetics with CAN compared with those without CAN. This implies that diabetics who carry $\mathrm{D}$ allele may be more prone to develop CAN compared with those carrying I allele.

Several studies demonstrated that the homozygous DD genotype of the I/D polymorphism could be considered as a risk factor for diabetic peripheral neuropathy (DPN). For example, the D allele was associated with an increased risk of DPN in females, but not in male patients with T2DM [37]. Similarly, in Turkey, a study compared 235 unrelated patients with T2DM with DPN and 281 unrelated healthy controls, and demonstrated that the DD genotype was associated with DPN [38].

Likewise, in Egyptian patients with T2DM (47 with DPN), logistic regression analysis showed that the $A C E$ $\mathrm{D} / \mathrm{D}$ genotype was associated with a threefold increase in the risk of developing DPN compared with healthy controls [39]. Further, a study conducted on the Asian population described a protective role of the $A C E$ II genotype against the development of DPN. According to the study, the prevalence of the II genotype was significantly higher than that of the DD genotype in patients with T2DM without DPN [40]. Moreover, the heterozygous genotype was found to be independently associated with a decreased risk of DPN in a population of North Catalonia [41].

\section{Limitations}

The main limitations of our study are the relatively small sample size that not all noninvasive tests for CAN diagnosis were employed and there was no follow-up. So, no data were available to determine the effect of CAN on clinical outcomes, and its long-term prognostic relevance. Moreover, the necessary data to evaluate the potential association between CAN and microvascular

Table 4 Frequency of different genotypes and allele of ACE ID polymorphism in patients with and without cardiac autonomic neuropathy

\begin{tabular}{|c|c|c|c|c|}
\hline \multirow{2}{*}{$\begin{array}{l}\text { ACE ID } \\
\text { polymorphism }\end{array}$} & \multicolumn{2}{|c|}{ Diabetic patients $n=117$} & \multirow{2}{*}{$\begin{array}{l}p \\
\text { value }\end{array}$} & \multirow[t]{2}{*}{ OR $(95 \% \mathrm{Cl})$} \\
\hline & With CAN $n=55$ & Without CAN $n=62$ & & \\
\hline \multicolumn{5}{|l|}{ Genotypes } \\
\hline$\|$ & $3(5.45 \%)$ & $7(11.29 \%)$ & 0.196 & 1.0 ref. \\
\hline ID & $14(25.45 \%)$ & $22(35.48 \%)$ & 0.608 & $1.5(0.33-6.71)$ \\
\hline DD & 38 (69.1\%) & $33(53.23 \%)$ & 0.176 & $2.7(0.64-11.24)$ \\
\hline HWE & 0.284 & 0.274 & & \\
\hline \multicolumn{5}{|l|}{ Alleles } \\
\hline । & $20(18.18 \%)$ & $36(29.03 \%)$ & 0.054 & 1.0 ref. \\
\hline D & 90 (81.82\%) & 88 (70.97\%) & & $1.84(0.99-3.42)$ \\
\hline
\end{tabular}

CAN cardiac autonomic neuropathy, HWE Hardy-Weinberg equilibrium (using logistic regression) 
complications such as nephropathy and retinopathy were not available.

\section{Conclusion}

Despite the somewhat small sample size of the current study compared with other epidemiologic and association studies, the results confirm the assumption that $\mathrm{D}$ allele is strongly associated with T2DM. The DD genotype was associated with a threefold increase in the risk of developing DM compared with healthy controls. Patients with diabetes who carry the $\mathrm{D}$ allele can be at greater risk for developing CAN as compared with those carrying the I allele.

\section{Abbreviations}

ACE: Aangiotensin-converting enzyme; Ang: Angiotensin; BMl: Body mass index; BP: Blood pressure; CAN: Cardiac autonomic neuropathy; Cl: Confidence interval; DNA: Deoxyribonucleic acid; ECG: Electroencephalography; EDTA: Ethylenediamine-tetraacetic acid; HbA1c: Glycosylated hemoglobin; HR: Heart rate; HWE: Hardy-Weinberg equilibrium; I:D: Insertion:deletion; IRB: Institutional Review Board; PCR: Polymerase chain reaction; RAS: Renin-angiotensin system; OR: Odds ratio; SNP: Single-nucleotide polymorphism; T2DM: Type 2 diabetes mellitus; WHR: Waist-hip ratio

\section{Acknowledgements}

We thank Professor Dr. Mahmood Shakir Khudhair from the Department of Medicine/Endocrinology, College of Medicine, Al-Nahrain University and AlImamain Al-Kadhimyian Medical City for examining and refereeing the diabetic cases. We thank Miss. Jasim EA and Miss. Ahmed IW from the Medical Research Unit, College of Medicine, Al-Nahrain University for assistance in DNA expression analysis.

\section{Authors' contributions}

All the authors have directly participated in the preparation of this manuscript and have approved the final version submitted. "MD" performed the Ewing's test. "AQ" performed the statistical analysis. "MD" drafted the manuscript. "AQ" and "FH" conceived of the study and participated in its design and interpretation. "AQ" and "FH" supported the manuscript drafting. All the authors have read and approved the final manuscript.

\section{Funding}

Self-funding

\section{Availability of data and materials}

All data generated or analyzed during this study are included in this published article. The datasets used and/or analyzed during the current study are available from the corresponding author on reasonable request.

\section{Ethics approval and consent to participate}

The study was approved by the Institutional Review Board (IRB) of the College of Medicine, Al-Nahrain University (decision number: $\mathrm{mmm} / 155$ : date: 11/12/2018). A written informed consent was obtained from all the participants.

\section{Consent for publication}

Not applicable

\section{Competing interests}

The authors declare that they have no competing interest.

\section{Author details}

${ }^{1}$ Section of Pharmacy, Baghdad College of Medical Sciences, Baghdad, Iraq. ${ }^{2}$ Department of Physiology, College of Medicine, Al-Nahrain University, P.O. Box 14222, Baghdad, Iraq. ${ }^{3}$ Medical Research Unit, College of Medicine, Al-Nahrain University, Baghdad, Iraq.
Received: 20 February 2020 Accepted: 17 April 2020

Published online: 11 May 2020

\section{References}

1. Spallone V, Ziegler D, Freeman R, Bernardi L, Frontoni S, Pop-Busui R et al (2011) Cardiovascular autonomic neuropathy in diabetes: clinical impact, assessment, diagnosis, and management. Diabetes Metab Res Rev. 27:639653

2. Osztovits J, Horváth T, Littvay L, Steinbach R, Jermendy A, Tárnoki A et al (2011) Effects of genetic vs. environmental factors on cardiovascular autonomic function: a twin study. Diabet Med. 28:1241-1248

3. Ciccacci C, Di Fusco D, Cacciotti L, Morganti R, D'Amato C, Novelli G et al (2013) TCF7L2 gene polymorphisms and type 2 diabetes: association with diabetic retinopathy and cardiovascular autonomic neuropathy. Acta Diabetol. 50:789-799

4. Politi C, Ciccacci C, D'Amato C, Novelli G, Borgiani P, Spallone V (2016) Recent advances in exploring the genetic susceptibility to diabetic neuropathy. Diabet Res Clin Pract. 120:198-208

5. Zhou YF, Yan H, Hou XP, Miao JL, Zhang J, Yin QX et al (2013) Association study of angiotensin-converting enzyme gene polymorphism with elderly diabetic hypertension and lipids levels. Lipids Health Dis. 12:187

6. Ormazabal V, Nair S, Elfeky O, Aguayo C, Salomon C, Zuñiga FA (2018) Association between insulin resistance and the development of cardiovascular disease. Cardiovasc Diabetol. 17:122

7. de Moraes OA, Flues K, Scapini KB, Mostarda C, Evangelista F, de Rodrigues $B$ et al (2018) ACE gene dosage determines additional autonomic dysfunction and increases renal angiotensin II levels in diabetic mice. Clinics (São Paulo, Brazil) 73:e246

8. Mengesha HG, Petrucka P, Spencem C, Tafesse TB (2019) Effects of angiotensin converting enzyme gene polymorphism on hypertension in Africa: a meta-analysis and systematic review. PLoS ONE. 14:e0211054

9. Mani D, Chinniah R, Ravi P, Swaminathan K, Janarthanan RA, Vijayan M et al (2017) Predisposition of angiotensin-converting enzyme deletion/deletion genotype to coronary artery disease with type 2 diabetes mellitus in South India. Indian J Endocrinol Metab. 21:882-885

10. Al-Harbi EM, Farid EM, Gumaa KA, Singh J (2012) Genotypes and allele frequencies of angiotensin-converting enzyme (ACE) insertion/deletion polymorphism among Bahraini population with type 2 diabetes mellitus and related diseases. Mol Cell Biochem. 362:219-223

11. Li X, Ooi FK, Zilfalil BA, Yusoff S. The influence of angiotensin-converting enzyme gene ID polymorphism on human physical fitness performance in European and other populations). Sport Sci Health. 2016. DOI https://doi. org/10.1007/s11332-016-0340-7.

12. Taal MW (2000) Angiotensin-converting enzyme gene polymorphisms in renal disease: clinically relevant? Curr Opin Nephrol Hypertens. 9:651-657

13. Moleda P, Majkowska L, Safranow K, Adler G, Goracy I (2007) Relationship between I/D polymorphism of angiotensin I converting enzyme gene and microvascular complications in type 2 diabetic patients. Przegl Lek. 64:134139

14. Abdalrada AS, Abawajy JH, Chowdhury MU, Rajasegarar S, Al-Quraishi T, Jelinek HF (2018) Relationship between angiotensin converting enzyme gene and cardiac autonomic neuropathy among Australian population. In: Ghazali R, Mat Deris M, Mohd Nawi N, Abawajy JH (eds) Recent Advances on Soft Computing and Data Mining - Proceedings of the 3rd International Conference on Soft Computing and Data Mining SCDM 2018, vol 700. Springer-Verlag London Ltd, Switzerland, pp 135-146

15. Spallone V, Bellavere F, Scionti L, Maule S, Quadri R, Bax G et al (2011) Recommendations for the use of cardiovascular tests in diagnosing diabetic autonomic neuropathy. Nutr Metab Cardiovasc Dis. 21:69-78

16. Boulton AJ, Vinik Al, Arezzo JC, Bril V, Feldman EL, Freeman R et al (2005) Diabetic neuropathies: a statement by the American Diabetes Association Diabetes Care. 28:956-962

17. Serhiyenko VA, Serhiyenko AA (2018) Cardiac autonomic neuropathy: risk factors, diagnosis and treatment. World J Diabetes. 9:1-24

18. Mansour A, Al DF (2015) Diabetes in Iraq: facing the epidemic. A systematic review. Wulfenia J. 22:258-273

19. Rudberg S, Rasmussen LM, Bangstad HJ, Osterby R (2000) Influence of insertion/deletion polymorphism in the ACE-I gene on the progression of diabetic glomerulopathy in type 1 diabetic patients with microalbuminuria. Diabetes Care. 23:544-548 
20. Goossens $\mathrm{GH}$ (2012) The renin-angiotensin system in the pathology of type 2 diabetes. Obes Facts 5:611-624

21. Degirmenci I, Kebapci N, Basaran A, Efe B, Gunes HV, Akalin A et al (2005) Frequency of angiotensin-converting enzyme gene polymorphism in Turkish type 2 diabetic patients. Int J Clin Pract. 59: 1137-1142

22. Tseng CH, Tseng CP, Chong CK, Sheu JJ, Cheng JC (2007) Angiotensin converting enzyme gene polymorphism and stroke in type 2 diabetic patients in Taiwan. Eur J Clin Invest. 37:483-491

23. Nikzamir A, Nakhjavani M, Golmohamadi T, Dibai L (2008) Association of angiotensin-converting enzyme gene insertion/deletion polymorphism with metabolic syndrome in Iranians with type 2 diabetes mellitus. Arch Iran Med. 11:3-9

24. Ghazali DM, Rehman A, Rahman AR (2008) Candidate gene polymorphisms and their association with hypertension in Malays. Clin Chim Acta. 88:46-50

25. Zarouk WA, Hussein IR, Esmaeil NN, Raslan HM, Reheim HA, Moguib O et al (2012) Association of angiotensin converting enzyme gene (I/D) polymorphism with hypertension and type 2 diabetes. Bratisl Lek Listy. 113: 14-18

26. Zhou TB, Yin SS, Qin YH (2014) Association between angiotensin-converting enzyme insertion/deletion gene polymorphism and end-stage renal disease susceptibility. J Renin Angiotensin Aldosterone Sys. 15:22-31

27. Al-Saikhan Fl, Abd-Elaziz MA, Ashour RH (2017) Association between risk of type 2 diabetes mellitus and angiotensin-converting enzyme insertion/ deletion gene polymorphisms in a Saudi Arabian population. Biomed Rep. 7:56-60

28. Daimon M, Oizumi T, Saitoh T, Kameda W, Hirata A, Yamaguchi H et al (2003) The $D$ allele of the angiotensin-converting enzyme insertion/ deletion (I/D) polymorphism is a risk factor for type 2 diabetes in a population-based Japanese sample. Endocrine J. 50: 393-398

29. Zhou D, Ruiter R, Zhang J, Zhou M, Liu H, Liu W et al (2012) Angiotensinconverting enzyme I/D polymorphism is not associated with type 2 diabetes in a Chinese population. J Renin Angiotensin Aldosterone Sys. 13: 372-378

30. Sarkar P, Chattrejee D, Bandyopadhyay AR (2016) A study on the association of ACE I/D gene polymorphism, obesity, blood pressure and susceptibility of type 2 diabetes mellitus among the Kurmis of West Bengal. India. J Immunol Geriat. 1:1-8

31. Doi $Y$, Yoshizumi $H$, Yoshinari $M$, lino $K$, Yamamoto $M$, Ichikawa $K$ et al (1996) Association between a polymorphism in the angiotensin-converting enzyme gene and microvascular complications in Japanese patients with NIDDM. Diabetologia. 39:97-102

32. Al-Serri A, Ismael FG, Al-Bustan SA, Al-Rashdan I (2015) Association of the insertion allele of the common ACE gene polymorphism with type 2 diabetes mellitus among Kuwaiti cardiovascular disease patients. J ReninAngiotensin Aldosterone Sys. 16:910-916

33. Barley J, Blackwood A, Cartere ND, Crews DE, Cruickshank JK, Jeffery S et al (1994) Angiotensin converting enzyme insertion/deletion polymorphism: association with ethnic origin. J Hypertens. 12:955-957

34. O'Donell CJ, Lindpaintner K, Larson MG, Rao VS, Ordovas JM, Schaefer EJ et al (1998) Evidence for association and genetic linkage of the angiotensin converting enzyme locus with hypertension and blood pressure in men but not women in the Framingham Heart Study. Circulation. 97:1766-1772

35. Cobiac $L$ (2007) Epigenomics and nutrition. Forum of Nutr. 60:31-41

36. Nakajim K, Takeoka M, Mori M, Hashimoto S, Sakurai A, Nose H et al (2010) Exercise effects on methylation of ASC gene. Int J Sports Med. 31:671-675

37. Stephens JW, Dhamrait SS, Acharya J, Humphries SE, Hurel SJ (2006) A common variant in the ACE gene is associated with peripheral neuropathy in women with type 2 diabetes mellitus. J Diabetes Complications. 20:317-321

38. Inanir A, Basol N, Karakus N, Yigit S (2013) The importance of association between angiotensin-converting enzyme (ACE) gene I/D polymorphism and diabetic peripheral neuropathy. Gene. 530:253-256

39. Settin A, El-Baz R, Ismaeel A, Tolba W, Allah WA (2015) Association of ACE and MTHFR genetic polymorphisms with type 2 diabetes mellitus: susceptibility and complications. J Renin-Angiotensin-Aldosterone Sys. 16: 838-843

40. Mansoor Q, Javaid A, Bilal N, Ismail M (2012) Angiotensin-converting enzyme (ACE) gene II genotype protects against the development of diabetic peripheral neuropathy in type 2 diabetes mellitus. J Diabetes. 4 257-261

41. Jurado J, Ybarra J, Romeo JH, Garcia M, Zabaleta-Del-Olmo E (2012) Angiotensin-converting enzyme gene single polymorphism as a genetic biomarker of diabetic peripheral neuropathy: longitudinal prospective study. J Diabetes Complications. 26:77-82

\section{Publisher's Note}

Springer Nature remains neutral with regard to jurisdictional claims in published maps and institutional affiliations.

\section{Submit your manuscript to a SpringerOpen ${ }^{\circ}$ journal and benefit from:}

- Convenient online submission

- Rigorous peer review

- Open access: articles freely available online

- High visibility within the field

- Retaining the copyright to your article

Submit your next manuscript at $\boldsymbol{\nabla}$ springeropen.com 